\title{
Effect of intercropping white cabbage with French Marigold (Tagetes patula nana L.) and Pot Marigold (Calendula officinalis L.) on the colonization of plants by pest insects
}

\author{
Beata Jankowska ${ }^{1}$, Matgorzata Poniedziatek ${ }^{2}$,Elżbieta Jędrszczyk ${ }^{2}$ \\ ${ }^{1}$ Department of Plant Protection \\ ${ }^{2}$ Department of Vegetable Crops and Horticultural Economics \\ Faculty of Horticulture, University of Agriculture in Krakow \\ 29 Listopada 54, 31-425 Kraków, Poland \\ e-mail: jankowskab@ogr.ar.krakow.pl
}

Key words: Lepidoptera cabbage pests, Brevicoryne brassicae L., Phyllotreta

\begin{abstract}
In 2003 - 2005 the impact of intercropping white cabbage 'Bently F1' with French Marigold (Tagetes patula nana 'Kolombina') and Pot Marigold (Calendula officinalis 'Promyk') on the occurrence of pest insects was estimated. On plots where cabbage was intercropped the number of cabbage aphid Brevicoryne brassicae L. and flea beetles Phyllotreta was significantly lower when compared with control variant (homogenous crop). Intercropping had an effect on the butterfly oviposition too. The lower number of eggs of the small white butterfly Pieris rapae L., large white butterfly $P$. brassicae L., cabbage moth Mamestra brassicae L. and larvae and pupae of the diamondback moth Plutella xylostella L. were observed on plots with Calendula and Tagetes. Intercropping with Pot Marigold was the most effective pest control on cabbage.
\end{abstract}




\section{INTRODUCTION}

Among the numerous phytophagous insects occurring on different botanical varieties of cabbage including white cabbage, the most important were cabbage aphid Brevicoryne brassicae L. (Jankowska and Wiech 2004), flea beetles Phyllotreta spp. (Szwejda 2004), and several Lepidoptera pests, such as the small white butterfly Pieris rapae L., large white butterfly Pieris brassicae L., cabbage moth Mamestra brassicae L. (Jankowska 2006), diamondback moth Plutella xylostella L. (Jankowska 2005), Contarinia nasturtii, and Delia radicum (Szwejda 2004). Each of these pests has the potential of reducing the marketable yield severely or completely destroying the crop. Chemical pest control generates ecological and toxicological problems. One of the alternative proposals to reduce losses from pest attack is intercropping and mixed cropping.

Many studies have shown that vegetative diversity in the form of intercropping can result in reduced pest densities and increases the resistance of the environment (Wiech and Kałmuk 2005). Andow (1991) analysed 209 studies involving 287 pest species. Compared with monocultures, the population of pest insects was lower in $52 \%$ of the studies (149 species). Intercropping systems favour the environment because they prevent soil from erosion, and influence soil structure as well. This system demands careful management for success. A very important factor is species assortment, which influences plants growth and yielding and pest population. Therefore, the aim of this investigation was to assess the influence of intercropping cabbage with Tagetes and Calendula on the infestation of some herbivorous cabbage pests.

\section{MATERIAL AND METHODS}

The investigation was carried out in 2003 - 2005 in Mydlniki near Kraków, Poland on brown soil developed on loess. A randomized block design was used in three replications on $10.8 \mathrm{~m}^{2}$ plots. The combinations of the experiment included three objects: a homogenous crop of white cabbage 'Bently $\mathrm{F}_{1}$ ', cabbage intercropping with Tagetes patula nana 'Kolombina' and cabbage intercropping with Calendula officinalis 'Promyk'. Tagetes and Calendula were sown on 22 April in 2003 - 2004, and 24 April in 2005. The cabbage was transplanted in spacing of $67.5 \times 40 \mathrm{~cm}$ between intercrop rows on 28 May in 2003 and 2004, and 3 June in 2005. No chemical treatments were applied and weeds were removed mechanically. Ten plants were selected and marked from each plot and every week were inspected, and winged and wingless forms of the cabbage aphid Brevicoryne brassicae L., flea beetles Phyllotreta sp. and eggs and larvae of the butterflies (Pieris rapae L., P. brassicae L., Mamestra brassicae L.) and larvae and pupae of DBM Plutella 
xylostella L. were counted. The number of plants damaged by swede midge Contarinia nasturtii (Kieffer) from each plot was recorded as well. The Duncan multiple test $(p=0.05)$ was used for the statistical analysis of the results.

\section{RESULTS AND DISCUSSION}

During the observations carried out in the years 2003 - 2005, plant infestation by the cabbage aphid $B$. brassicae L. differed in accordance to the type of cultivation. All observed combinations were colonized in the same term, but the number of aphids landing on plants differed. More winged aphids and more colonizers were recovered from the plots with cabbage alone than from cabbage intercropped (Table 1). The total number of aphids occurring on plots intercropped with Tagetes was 2-7 times less and with Calendula was 8-24 times less than in the monoculture (Table 1). In all the years of research the percentage of plants infested by aphids was significantly higher in plots with a homogenous crop of cabbage (Table 1). Many studies have shown that intercropping cabbage with other plants can result in reducing cabbage aphid (Theunissen and Den Ouden 1980, Wiech 1993, Vidal and Bohlsen 1994, Costello 1995, Vidal 1997, Lehmus et al. 1999, Bukovinszky et al. 2003, Kienegger et al. 2003).

Two flea beetle species were noted during the study: Phyllotreta nemorum L. and Phyllotreta atra Fabr. P. nemorum was the dominant flea beetle species in all the years of observation and in every combination. The number of beetles on cabbage plants growing on plots with $C$. officinalis and with $T$. patula was significantly lower compared with the cabbage monoculture (Table 2). Latheef et al. (1984) observed that beetle populations were significantly smaller, and collard foliage was damaged significantly less in intercropped collards than monocropped collards. According to Tahvanainen and Root (1972), the highly odours ragweed Ambrosia artemisifolia could be used to repel the flea beetle $P$. cruciferae from a collard crop.

Fewer eggs of the small white butterfly Pieris rapae L. (Table 3) and cabbage moth Mamestra brassicae L. (Table 4) were observed on intercropped plots. Koehler et al. (1983) studied several medicinal plants and herbs and found that the aforementioned plants, planted near cabbage, reduced the abundance of $P$. rapae on cabbage. Lundgren (1975) noted that adults of $P$. rapae did not lay eggs on cabbage plants in the company of Salvia horminum. According to many authors, egg densities of $P$. rapae were not influenced by cropping system (Maguire 1983, Clough et al. 2002). Metspalu et al. (2003) showed that T. patula were oviposition repellent to Pieris brassicae, but the butterflies laid early eggs on cabbage plants surrounded by $C$. officinalis. 
On intercropped plots fewer larvae and pupae of the diamondback moth (Plutella xylostella L.) were noted compared with a cabbage monoculture (Table 5). Many studies reported a lower abundance of $P$. xylostella in intercropping system with labiate herbs (Dover 1986), subterranean clover (Finch and Kienegger 1997), strawberry clover (Theunissen and Schelling 1996), white clover (Dover 1986, Wiech 1993), and red clover (Åsman et al. 2001). Compared with homogenous crops, the losses caused by swede midge Contarinia nasturtii were also smaller (Table 6).

Table 1. Selected information concerning cabbage aphid (Brevicoryne brassiceae L.) occurrence on cabbage according to the type of cultivation $(2003-2005)$

\begin{tabular}{|c|c|c|c|}
\hline \multirow[b]{2}{*}{$\begin{array}{l}\text { Selected } \\
\text { information }\end{array}$} & \multicolumn{3}{|c|}{ Type of cultivation } \\
\hline & $\begin{array}{c}\text { Cabbage } \\
\text { (homogenous } \\
\text { crop) }\end{array}$ & $\begin{array}{l}\text { Cabbage with } \\
\text { Tagetes patula }\end{array}$ & $\begin{array}{c}\text { Cabbage with } \\
\text { Calendula } \\
\text { officinalis }\end{array}$ \\
\hline \multicolumn{4}{|c|}{2003} \\
\hline $\begin{array}{l}\text { Mean number of migrants per } \\
\text { plant }\end{array}$ & $1.80 \mathrm{~b}^{*}$ & $0.01 \mathrm{a}$ & $0.00 \mathrm{a}$ \\
\hline $\begin{array}{l}\text { Mean number of aphids per plant } \\
\% \text { of plants with aphids }\end{array}$ & $44.20 \mathrm{c}$ & $5.73 \mathrm{~b}$ & $0.20 \mathrm{a}$ \\
\hline 17.06 & $33.30 \mathrm{~b}$ & $0.00 \mathrm{a}$ & $0.00 \mathrm{a}$ \\
\hline 03.07 & $50.00 \mathrm{~b}$ & $10.00 \mathrm{a}$ & $33.00 \mathrm{a}$ \\
\hline \multicolumn{4}{|c|}{2004} \\
\hline $\begin{array}{l}\text { Mean number of migrants per } \\
\text { plant }\end{array}$ & $3.00 \mathrm{~b}$ & $0.90 \mathrm{a}$ & $0.40 \mathrm{a}$ \\
\hline $\begin{array}{l}\text { Mean number of aphids per plant } \\
\% \text { of plants with aphids }\end{array}$ & $54.60 \mathrm{c}$ & $11.30 \mathrm{~b}$ & $2.30 \mathrm{a}$ \\
\hline 28.06 & $64.00 \mathrm{~b}$ & $30.00 \mathrm{a}$ & $26.00 \mathrm{a}$ \\
\hline 09.07 & $93.00 \mathrm{~b}$ & $36.00 \mathrm{a}$ & $30.00 \mathrm{a}$ \\
\hline \multicolumn{4}{|c|}{2005} \\
\hline $\begin{array}{l}\text { Mean number of migrants per } \\
\text { plant }\end{array}$ & $2.18 \mathrm{~b}$ & $0.30 \mathrm{a}$ & $0.20 \mathrm{a}$ \\
\hline Mean number of aphids per plant & $165.70 \mathrm{c}$ & $64.50 \mathrm{~b}$ & $20.60 \mathrm{a}$ \\
\hline $\begin{array}{l}\text { Mean number of aphids per plant } \\
\text { in period of max. infestation } \\
15.07\end{array}$ & $435.90 \mathrm{c}$ & $151.90 \mathrm{~b}$ & $49.30 \mathrm{a}$ \\
\hline \multicolumn{4}{|l|}{$\%$ of plants with aphids } \\
\hline 22.06 & 69.20 & 19.20 & 7.50 \\
\hline 13.07 & 100.00 & 99.00 & 74.00 \\
\hline 10.08 & 100.00 & 100.00 & 80.00 \\
\hline
\end{tabular}

*Values followed by the same letter do not differ at the $5 \%$ level of significance (Duncan's multiple test) 
Table 2. Occurrence of flea beetles (Phyllotreta sp.) on cabbage according to the type of cultivation $(2003-2005)$

\begin{tabular}{lccc}
\hline \multirow{2}{*}{ Type of cultivation } & \multicolumn{3}{c}{ Mean number of beetles / plant } \\
\cline { 2 - 4 } & 2003 & 2004 & 2005 \\
\hline Cabbage (homogenous crop) & $9.70 \mathrm{~b}^{*}$ & $9.70 \mathrm{~b}$ & $2.40 \mathrm{~b}$ \\
Cabbage with Tagetes patula & $0.08 \mathrm{a}$ & $0.00 \mathrm{a}$ & $0.08 \mathrm{a}$ \\
Cabbage with Calendula officinalis & $0.03 \mathrm{a}$ & $0.33 \mathrm{a}$ & $0.00 \mathrm{a}$ \\
\hline
\end{tabular}

* Explanations: see Table 1

Table 3. Occurrence of small white butterfly (Pieris rapae L.) eggs and caterpillars on the cabbage according to the type of cultivation (2003-2005)

\begin{tabular}{lcccccc}
\hline \multirow{2}{*}{ Type of cultivation } & \multicolumn{6}{c}{ Mean number / plant } \\
\cline { 2 - 7 } & \multicolumn{2}{c}{2003} & \multicolumn{2}{c}{2004} & 2005 \\
\cline { 2 - 7 } & Eggs & Larvae & Eggs & Larvae & Eggs & Larvae \\
\hline Cabbage (homogenous crop) & $5.50 \mathrm{~b}^{*}$ & $2.75 \mathrm{a}$ & $9.60 \mathrm{~b}$ & $3.20 \mathrm{a}$ & $4.00 \mathrm{~b}$ & $2.00 \mathrm{a}$ \\
Cabbage with Tagetes patula & $4.00 \mathrm{~b}$ & $2.50 \mathrm{a}$ & $3.00 \mathrm{a}$ & $1.00 \mathrm{a}$ & $1.30 \mathrm{a}$ & $2.00 \mathrm{a}$ \\
Cabbage with Calendula officinalis & $1.50 \mathrm{a}$ & $1.75 \mathrm{a}$ & $2.00 \mathrm{a}$ & $2.00 \mathrm{a}$ & $1.30 \mathrm{a}$ & $1.00 \mathrm{a}$ \\
\hline
\end{tabular}

* Explanations: see Table 1

Table 4. Occurrence of cabbage moth (Mamestra brassicae L.) eggs on the cabbage according to the type of cultivation $(2003-2005)$

\begin{tabular}{lcccccc}
\hline & \multicolumn{6}{c}{ Mean number/30 plants } \\
\cline { 2 - 7 } Type of cultivation & \multicolumn{2}{c}{2003} & \multicolumn{2}{c}{2004} & \multicolumn{2}{c}{2005} \\
\cline { 2 - 7 } & $\begin{array}{c}\text { Egg } \\
\text { clusters }\end{array}$ & Eggs & $\begin{array}{c}\text { Egg } \\
\text { clusters }\end{array}$ & Eggs & $\begin{array}{c}\text { Egg } \\
\text { clusters }\end{array}$ & Eggs \\
\hline Cabbage (homogenous crop) & $3.50 \mathrm{~b}^{*}$ & $58.80 \mathrm{~b}$ & $4.00 \mathrm{~b}$ & $68.00 \mathrm{~b}$ & $2.00 \mathrm{~b}$ & $20.00 \mathrm{~b}$ \\
Cabbage with Tagetes patula & $1.50 \mathrm{~b}$ & $17.50 \mathrm{~b}$ & $2.50 \mathrm{~b}$ & $30.00 \mathrm{~b}$ & $0.00 \mathrm{a}$ & $0.00 \mathrm{a}$ \\
Cabbage with Calendula & $0.00 \mathrm{a}$ & $0.00 \mathrm{a}$ & $0.00 \mathrm{a}$ & $0.00 \mathrm{a}$ & $0.00 \mathrm{a}$ & $0.00 \mathrm{a}$ \\
officinalis & & & & & &
\end{tabular}

* Explanations: see Table 1

Table 5. Occurrence of diamondback moth (Plutella xylostella L.) larvae and pupae on the cabbage according to the type of cultivation (2003 - 2005)

\begin{tabular}{lccc}
\hline \multirow{2}{*}{ Type of cultivation } & \multicolumn{3}{c}{ Mean number / 30 plants } \\
\cline { 2 - 4 } & 2003 & 2004 & 2005 \\
\hline Cabbage (homogenous crop) & $13.00 \mathrm{~b}^{*}$ & $4.80 \mathrm{~b}$ & $5.30 \mathrm{~b}$ \\
Cabbage with Tagetes patula & $9.30 \mathrm{~b}$ & $1.00 \mathrm{a}$ & $0.80 \mathrm{a}$ \\
Cabbage with Calendula officinalis & $3.50 \mathrm{a}$ & $0.20 \mathrm{a}$ & $0.20 \mathrm{a}$ \\
\hline
\end{tabular}

* Explanations: see Table 1 
Table 6. Occurrence of swede midge Contarinia nasturtii (Kieffer) on the cabbage according to the type of cultivation $(2003-2005)$

\begin{tabular}{lccc}
\hline \multirow{2}{*}{ Type of cultivation } & \multicolumn{3}{c}{ Plants damaged by swede midge (\%) } \\
\cline { 2 - 4 } & 2003 & 2004 & 2005 \\
\hline Cabbage (homogenous crop) & $27.50 \mathrm{~b} *$ & $16.70 \mathrm{~b}$ & $3.30 \mathrm{~b}$ \\
Cabbage with Tagetes patula & $4.20 \mathrm{a}$ & $7.50 \mathrm{a}$ & $0.80 \mathrm{a}$ \\
Cabbage with Calendula officinalis & $16.70 \mathrm{~b}$ & $8.30 \mathrm{a}$ & $0.80 \mathrm{a}$ \\
\hline
\end{tabular}

* Explanations: see Table 1

Diversity of plants in agrocenosis may be an important factor that influences the presence of pests as well as their natural enemies. Jankowska (2007) noted that on plots where cabbage was intercropped with Pot Marigold and French Marigold, cabbage aphid parasitisation by Diaeretiella rapae M'Intosh was greater and the percentages of predatory Syrphidae to prey were more favourable than on homogenous crops. The combination with Pot Marigold turned out to be the best in this respect.

\section{CONCLUSIONS}

1. The number of cabbage aphid Brevicoryne brassicae L. and flea beetles (Phyllotreta) was significantly lower on plots where cabbage was intercropped with Pot Marigold and French Marigold in comparison with homogenous crops.

2. Intercropping had an effect on the oviposition of the small white butterfly Pieris rapae L., large white butterfly P. brassicae L., cabbage moth Mamestra brassicae L. and diamondback moth Plutella xylostella L.

3. Intercropping with Pot Marigold was the most effective in limiting pests on cabbage.

\section{REFERENCES}

ANDOW D.A., 1991. Vegetational diversity and arthropod population response. Ann. Rev. Entomol. 36: 561-568.

ÅsMAN K., EKBOM B., RÄMERT B., 2001. Effect of Intercropping on oviposition and emigration behavior of the leek moth (Lepidoptera: Acrolepiidae) and the diamondback moth (Lepidoptera: Plutellidae). Environ. Entomol. 30(2): 288-294. 
BUKOVINSZKY T., RASZTIK V., LENTERN VAN J.C., Vet L.E.M., BujÁKi G., 2003. The effects of undersowing (Brussels sprouts - black mustard) on population density of Brevicoryne brassicae and natural enemies of aphids. IOBC/WPRS Bull. 26(3): 167-176.

Clough Y., BukovinszKY T., LeNTERN VAN J.C., Vet L.E.M., 2002. Evaluating pest pressure in the Brussels sprout - barley intercropping system: influence of host plant patch size and surrounding vegetation. Proc. Exp. Appl. Entomol. 13: $123-124$.

COSTELLO M.J., 1995. Spectral reflectance from a broccoli crop with vegetation or soil as background: influence on immigration by Brevicoryne brassicae and Myzus persicae. Entomol. Exp. Appl. 75: 109-118.

DOVER J.W., 1986. The effect of labiate herbs and white clover on Plutella xylostella oviposition. Entomol. Exp. Appl. 39: 177-182.

FinCH S., KiENEGGER M., 1997. A behavioural study to help clarify how undersowing with clover effects host - plant selection by pest insects of Brassica crops. Entomol. Exp. Appl. 84: 165-172.

JANKOWSKA B., 2005., The comparison of the occurrence of the diamondback moth Plutella xylostella L. (Lepidoptera, Plutellidae) on the different cabbage vegetables. Veg. Crops Res. Bull. 62: 153-163.

JANKOWSKA B., 2006. The occurrence of some Lepidoptera pests on different cabbage vegetables. J. Plant Prot. Res. 46(2): 181-190.

JANKOWSKA B., 2007. Impact of intercropping white cabbage with Pot Marigold (Calendula officinalis L.) and French Marigold (Tagetes patula nana) on the occurrence of cabbage aphid (Brevicoryne brassicae L.), its parasitoid Diaeretiella rapae M'Intosh and predatory Syrphidae. Aphids and Other Hemipterous Insects 13: 199-209.

JANKOWSKA B., Wiech K., 2004. The comparison of the occurrence of the cabbage aphid (Brevicoryne brassicae L.) on the cabbage vegetables. Veg. Crops Res. Bull. 60: 71-80.

KoehleR I.C.S., BARClay L.W., KretChUN T.M., 1983. Companion plants. California Agric. 37(9/10): 11-12.

KienegGer M., Kromp B., KAHRER A., 2003. The effect of strips of flowers on pests and beneficial arthropods in adjacent broccoli plots. IOBC/WPRS Bull. 26(3): 61-69.

LATHEEF M.A., IRWIN R.D., 1979. The effect of companionate planting on lepidopteran pests of cabbage. The Canadian Entomologist 111: 863-864. 
LATHEeF M.A., ORTIZ J.H., ShEIKH A.Q., 1984. Influence of intercropping on Phyllotreta cruciferae (Coleoptera: Chrysomelidae) populations on collard plants. J. Econ. Entomol. 77: 1180-1184.

LeHMUS J., Hommes M., VidAL S., 1999. The impact of different intercropping systems on herbivorous pest insects in plots of white cabbage. IOB/WPRS Bull. 22(5): 163-169.

LUNDGREN N., 1975. Natural plant chemicals acting as oviposition deterrents on cabbage butterflies (Pieris brassicae (L.), P. rapae (L.), and P. napi (L.)). Zoologia Scripta 4: 253-258.

MAGUIRE L., 1983. Influence of collard patch size on population densities lepidopteran pests (Lepidoptera: Pieridae, Plutellidae). Environ. Entomol. 12: 1415-1419.

MetasPalu L., HiIeSAAR K., JÕGAR K., 2003. Plants influencing the behaviour of Larg White Butterfly (Pieris brassicae L.). Agron. Res. 1(2): 211-220.

SZWEJDA J., 2004. Review of pests and their natural enemies actually occurring on cabbages in Poland. Vegetable Crops News, Skierniewice: 97-104.

TAHVANAINEN J.O., RоOT R.B., 1972. The influence of vegetational diversity on the population ecology of a specialized herbivore Phyllotreta cruciferae (Coleoptera: Chrysomelidae). Oecologia 10: 321-346.

Theunissen J., Den OUDEN H., 1980. Effects of intercropping with Spergula arvensis on pests of Brussels sprouts. Entomol. Exp. Appl. 27: 260-268.

THEUNISSEN J., SCHELling G., 1996. Undersowing crops of white cabbage with strawberry clover and spurrey. IOBC/WPRS Bull. 19: 128-135.

VIDAL S., 1997. Factors influencing the population dynamics of Brevicoryne brassicae in undersown Brussels sprout. Biol. Agric. Hort. 15: 285-295.

VIDAL S., BOHLSEN W., 1994. What makes intercropped cauliflower plants less susceptible to Brevicoryne brassicae? International Control in Field Vegetable Crops. IOBC/WPRS Bull. 17(8): 173-182.

WIECH K., 1993. Wpływ współrzędnej uprawy późnej kapusty z koniczyną białą i fasolą szparagową na występowanie szkodliwej i pożytecznej entomofauny. Zesz. Probl. AR Kraków, Ser. Rozpr. 177, 74 pp.

WIECH K., KAŁMUK J., 2005. Uprawy współrzędne sposobem na zmniejszenie zużycia pestycydów. In: Ochrona środowiska naturalnego w XXI wieku, nowe wyzwania i zagrożenia. Fundacja na rzecz wspierania badań naukowych W.O., AR w Krakowie: 126-136. 
WPŁYW UPRAWY WSPÓŁRZĘDNEJ KAPUSTY BIAŁEJ Z AKSAMITKĄ (TAGETES PATULA NANA) I NAGIETKIEM (CALENDULA OFFICINALIS) NA ZASIEDLENIE PRZEZ SZKODLIWĄ ENTOMOFAUNĘ

Streszczenie: W latach 2003 - 2005 oceniano wpływ współrzędnej uprawy kapusty białej ('Bently $\mathrm{F}_{1}$ ') $\mathrm{z}$ aksamitką niską pełną Tagetes patula nana 'Kolombina' i nagietkiem lekarskim Calendula officinalis 'Promyk' na występowanie szkodliwej entomofauny. Na kapuście uprawianej współrzędnie z aksamitką i nagietkiem obserwowano istotnie mniej mszycy kapuścianej Brevicoryne brassicae L. i chrząszczy pchełek ziemnych Phyllotreta w porównaniu $\mathrm{z}$ uprawą jednorodną. Uprawa współrzędna wpływała także na składanie jaj przez motyle. Obserwowano tam mniej jaj bielinka rzepnika Pieris rapae L., bielinka kapustnika $P$. brassicae L., piętnówki kapustnicy Mamestra brassicae L. oraz gąsienic i poczwarek tantnisia krzyżowiaczka Plutella xylostella L. Najskuteczniej liczebność fitofagów na kapuście ograniczała uprawa współrzędnie z nagietkiem. 